\title{
Knowing a socially sustainable forest when you see one: Implications for results-based forestry
}

\author{
by Stephen Sheppard ${ }^{1}$
}

The wider forestry community is struggling to define what the third leg of sustainability—social sustainability-actually means. While work is now underway to develop better social Criteria and Indicators for sustainable forest management in BC and elsewhere, it is already becoming clear that the social process of decision-making and management can be as important to society as the social outcomes. This has significant implications for a results-based system such as certification or a new Forestry Code in BC. This paper explores what a truly open and accountable planning process might look like. The achievement of social sustainability depends in part on society seeing tangible proof that forestry is ecologically sustainable and carefully designed. For many of the local and global publics, the forest landscape itself provides strong evidence of forest manager's performance. The concept of Visible Stewardship, the obvious expression of care and commitment to sustainable forestry, and emerging tools such as computer visualisation of future forests, may be vital to building trust in sustainable forestry.

Key words: social sustainability, social criteria and indicators, public involvement, forest stewardship, visual quality, visualization, public perceptions

L'ensemble de la communauté forestière cherche à définir ce que le troisième aspect de la durabilité, la durabilité sociale, signifie réellement. Même si des travaux sont en cours pour élaborer de meilleurs Critères et Indicateurs sociaux de l'aménagement forestier durable en C.-B. et ailleurs au pays, il est de plus en plus évident que le processus social de prise de décision et d'aménagement peut être autant important pour la société que ses retombées. Cela entraîne des implications significatives pour un système reposant sur les résultats tel que la certification ou le nouveau Code forestier de la C.-B. Cet article explore ce qu'un processus de planification pleinement ouvert et redevable pourrait avoir l'air. L'atteinte de la durabilité sociale dépend en partie de la capacité de la société de voir les preuves tangibles que la foresterie est écologiquement durable et est soigneusement planifiée. Pour plusieurs des publics locaux et mondiaux, le paysage forestier en lui-même constitue une preuve indéniable de la performance de l'aménagiste forestier. Le concept de d'Intendance visible, l'expression évidente des soins et de l'engagement pris envers la foresterie durable, et de nouveaux outils comme la visualisation par voie informatique des forêts à venir, peuvent être essentiels pour élaborer des liens de confiance en foresterie durable.

Mots-clés: durabilité sociale, critères et indicateurs sociaux, participation du public, intendance forestière, qualité visuelle, perceptions du public

\section{Introduction}

This paper explores aspects of two basic questions central to socially sustainable forest management: what does social sustainability mean, and how do you recognize it when it is there? It also examines potential implications of these questions for current movements towards a more results-based framework for forestry, and concludes with some recommendations for forest policy, practice, and research.

The wider forestry community is struggling to define what the third leg of sustainability—social sustainability—actually means. Considerable work is now underway to develop social criteria and indicators (C\&Is) for sustainable forest management in BC and elsewhere (e.g., von Mirbach 2000, Achiam and Sheppard 2001, Sustainable Forest Management Network 2001, White 2001). This paper is not intended as a definitive review of social C\&Is, but rather, a selective examination of aspects of social sustainability that hinge upon the concepts of visibility and transparency: how the wider society can be kept informed of and involved in forest management decision-making (Fig. 1) and actual management performance. These concepts are central to the notion of an open and accountable forest management system.

This paper builds upon some important presumptions which should be laid out but will not be dwelt upon further here:

${ }^{1}$ Director, Collaborative for Advanced Landscape Planning, Faculty of Forestry/Landscape Architecture, University of British Columbia, 2045-2424 Main Mall, Vancouver, BC V6T 1Z4. E-mail: shep@interchange.ubc.ca
- The importance of the social sciences in forestry: the power of public perceptions, ill-informed or otherwise, in the forestry marketplace has proven beyond any doubt the necessity of dealing with this phenomenon directly and seriously. Yet, as White (2001) points out, social and even economic elements of sustainability are often an afterthought in forest

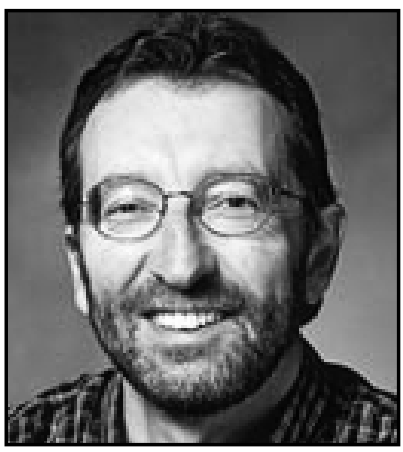

Stephen Sheppard research programs. Agencies such as the BC Ministry of Forests currently employ few social scientists.

- The weakness of social criteria and indicators in most certification programs and monitoring systems to date: International agreements such as the Montreal Process (Anon. 1995) provide for institutional processes, and national systems such as the Canadian Council of Forest Ministers (1995) C\&Is call for participatory approaches and respect for people's rights; however, there is seldom comprehensive or detailed guidance on social objectives, measures, and methods (Hislop and Twery 2001, Sheppard and Achiam 2001). As Burley (2001) says, "for some criteria, no good quantitative indicators have yet been developed, particularly 
for social benefits." It is not uncommon on forests certified under schemes such as the Canadian Standards Association (CSA) to find social indicators that are few in number, incomplete, and often vague or largely meaningless: e.g., "Hold two public meetings a year." Is that a good measure of performance?

- The arbitrary nature of the separation of economic and social criteria of sustainability: while the "three-legged stool" of sustainability has been widely accepted, in reality there is a large area of overlap between economic issues and the range of other human needs. However, we shall focus here on what we might call the socio-cultural aspects of sustainability, rather than the "hard" economic C\&Is which have been more commonly accepted for some time as a part of forest management. The more "fuzzy" socio-cultural issues can be important to public perceptions of forestry, but are harder to quantify and have usually been ignored in efforts to apply "science" to forest management: These issues include such things as aesthetics, spirituality, nostalgia for the past, general unease over forest practices and equity in the decision-making process.

- Recognition that the full range of forest values cannot ultimately be reduced to a simple list of quantifiable criteria and indicators: as Jim Webb of the Sustainable Forest Management Network has argued, a focus on basic science is incomplete because many of the questions in forest management are questions about human uses and relative values, not fundamentals of natural science (Webb 2001). Even the social sciences are likely to come up short in their ability to measure and predict the full range of interacting human emotions and behaviours that affect forestry decisions and management in reality. The most we can hope to do is sharpen some of the blunt instruments that are available to work on these problems.

\section{Critical Aspects of Socially Sustainable Forest Management: What Does it Mean?}

While the difficulty of defining social sustainability has been acknowledged from the beginning (Brand 1997), recent reviews of social C\&Is now emerging (e.g., von Mirbach 2000, Achiam and Sheppard 2001) suggest the following categories, which help us define some of the critical values and expectations that society is looking for in sustainable forest management (SFM):

\section{Social processes followed in SFM}

These include the use of decision-making and management processes that consider a range of social values, incorporate public input in a fair, open, and informative manner, and are effective. The mechanics of the public processes followed are usually documented at the time, and can be readily reviewed by outside experts later. Standards for assessing the fairness and effectiveness of the processes are not widely agreed, however (Hislop and Twery 2001).

\section{Social outcomes of SFM}

Direct socio-cultural outcomes/conditions: Sustainability of desired social values, resources or conditions that directly affect human security, wellness and enjoyment. Examples include quality of life factors, recreational opportunities and access, visual quality, risks and hazards, and available community services. These qualitative and quantitative conditions are not necessarily

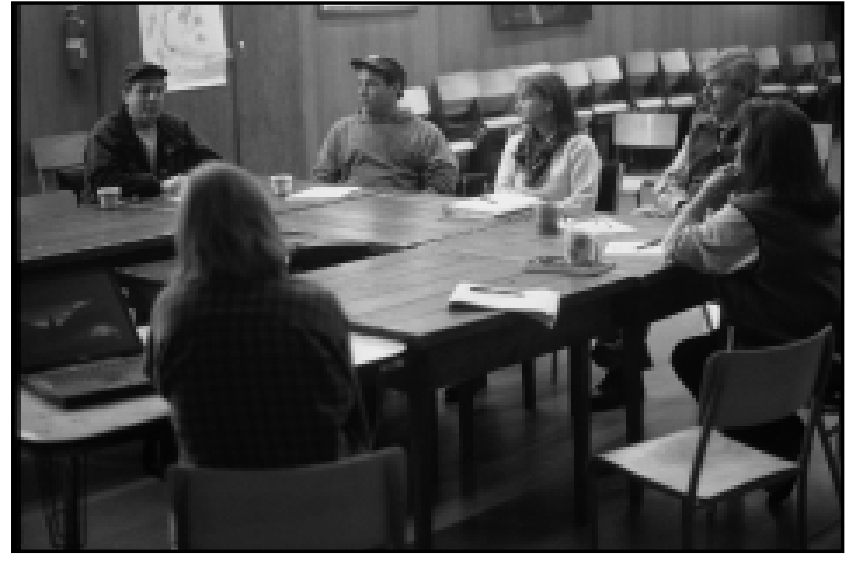

Fig.1. Stakeholder workshop to test decision-making processes in the Arrow Forest District, BC. Credit: Stephen R. J. Sheppard.

assessed using public or stakeholder opinion, but are often estimated or measured directly via technical or scientific studies; they are often at least partly quantifiable, and tend to be expert-based and more or less verifiable by other experts using generally accepted analysis methodologies, e.g., the Recreation Opportunity Spectrum (BCMOF 1998) for assessing impacts on recreation settings (Meitner et al. 2002), or the BC Visual Impact Assessment Procedure (BCMOF 2001).

Perceptions of, or satisfaction with, forest management: This includes people's views on both the procedures in place and the outcomes of management. Examples include levels of satisfaction with planning processes (e.g., the perceived fairness and overall success of the process), perceived trends in the quality of recreational experiences or level of risk (which may differ from the technical assessment of these indicators), and acceptability of forest management practices. These indicators can be measured through social science instruments such as user surveys and opinion polls, or through less sophisticated but more pragmatic methods such as recorded public comments, complaints or practitioners' observations.

Capacity-building and level of understanding: Advancement in people's level of awareness and understanding of SFM and its consequences for communities and interests. This calls for more transfer of information and technology to communities on forestry issues and other forms of capacity-building. These indicators can be measured formally through participant surveys (as above), or assessed more generally through observation of behaviour and capabilities of the affected social groups. It should be noted that information transfer is a two-way process and some of the more important social outcomes of SFM may be an improved awareness of social concerns and impacts on the part of the foresters.

Table 1 places these social functions into a possible framework for organizing and selecting socio-cultural C\&Is at the local level. It is not an attempt to categorize all types of social C\&Is. The suggested framework recognizes the distinction between procedural C\&Is and outcome-based or results-based C\&Is.

Examples of all these types of C\&Is can be found in current SFM evaluation systems. However, the different types appear at very different frequencies. In a quick classification of the C\&Is in use on the eleven Model Forests within the Canadian Model 
Table 1. Working framework for social sustainability indicators

\begin{tabular}{|c|c|c|c|c|}
\hline $\begin{array}{l}\text { Criteria \& } \\
\text { Indicators }\end{array}$ & Social sustainability criteria & \multicolumn{3}{|c|}{ Social sustainability indicators } \\
\hline Procedural & $\begin{array}{l}\text { A. Fair and effective } \\
\text { social processes }\end{array}$ & Inclusive/equitable process & \multicolumn{2}{|c|}{$\begin{array}{l}\text { Inclusiveness of people/institutions } \\
\text { Inclusiveness of values } \\
\text { Inclusiveness of ideas/choices/alternatives }\end{array}$} \\
\hline & & Informative process & \multicolumn{2}{|c|}{ Information availability } \\
\hline & & Effective process & \multicolumn{2}{|l|}{ Efficiency of process } \\
\hline & & & \multicolumn{2}{|c|}{ Conclusiveness of process result } \\
\hline \multirow[t]{11}{*}{ Outcome-based } & B. Beneficial social outcomes & B1. Directly measurable & \multirow{5}{*}{\multicolumn{2}{|c|}{$\begin{array}{l}\text { Recreational opportunities } \\
\text { Visual quality } \\
\text { Quality of water supply } \\
\text { Safety and security } \\
\text { Etc. }\end{array}$}} \\
\hline & & socio-cultural conditions & & \\
\hline & & (expert-driven) & & \\
\hline & & & & \\
\hline & & & & \\
\hline & & B2. Satisfaction/perceptions & Satisfaction with procedures & $\begin{array}{l}\text { Forest management/ecological } \\
\text { procedures (e.g., forest practices) }\end{array}$ \\
\hline & & & & \\
\hline & & & Satisfaction with outcomes & $\begin{array}{l}\text { Ecological outcomes (e.g., perceived for- } \\
\text { est health) }\end{array}$ \\
\hline & & & & $\begin{array}{l}\text { Economic outcomes (e.g. perceived eco- } \\
\text { nomic health) }\end{array}$ \\
\hline & & & & $\begin{array}{l}\text { Social outcomes (e.g. perceived qual- } \\
\text { ity of water supply, perceived quali- } \\
\text { ty of recreation) }\end{array}$ \\
\hline & & B3. Capacity/understanding & \multicolumn{2}{|c|}{$\begin{array}{l}\text { Level of knowledge and capability in ecological, economic, and social } \\
\text { factors. }\end{array}$} \\
\hline
\end{tabular}

Forest Network (von Mirbach 2000 and summarized in Table 2), I found that $46 \%$ of the 134 indicators reported under the main social categories (Criteria 5 and 6, exclusive of purely economic categories) are of the procedural type. Of the remaining $54 \%$, which relate to social outcomes of forest management, the majority (39\% of the total) falls within the direct social outcomes/conditions category, as measured largely by experts. Only $2 \%$ appear to deal explicitly with people's satisfaction with the SFM process or outcomes! Similar patterns are believed to occur with other C\&I systems.

The remainder of this section discusses the issues arising from this classification, and focuses primarily on:

- the role of social processes in SFM, especially the nature of public involvement processes in the planning and decisionmaking stage (A. in Table 1); and

- the importance of community perceptions and satisfaction with forest management (B2. in Table 1).

Table 1 highlights these areas in the framework for Sociocultural C\&Is.

\section{The importance of the social process}

From the time of the Montreal Process, the need for procedural components of social sustainability has been clearly recognized. The CCFM criterion of "accepting societies' responsibility for sustainable management" includes the need for transparent and participatory decision-making, and an efficient and informed process (CCFM 1995, Brand 1997). As described above as an example, almost half of the social indicators used by the Model Forests are procedural in nature. One reason for the abundance of procedural social indicators is that they are much easier to measure and document than "fuzzy" social outcomes: attendance at the meetings, for example, is much easier to document and quantify than the increase in awareness or level of satisfaction resulting from those meetings.
What has perhaps not been so clear is the relative importance of procedural versus outcome-based indicators. Researchers who routinely work with public processes tell us that the social process of decision-making and management can be as important to society as the social outcomes (Hislop and Twery 2001, Kruger 2001). In other words, it is not just what is done on the land, it is how the decision gets made. How people judge the acceptability of forest practices can depend in part on what they think of the decision-making process (Kruger 2001, citing Stankey 1996 and Shindler and Cramer 1999). This includes the fundamental human concern of not being left out of any decision-making process that might affect you, your community, or your interests. By extension, it is possible that the same practice would be entirely acceptable under one planning process or management regime, and entirely unacceptable with another. Experience with community forests such as North Cowichan (Allen and Frank 1994), where income from harvesting flows directly to the community's coffers and affected stakeholders can walk into the municipal foresters' or elected official's office at any time to complain or ask questions, suggests that visible clearcutting, for instance, is accepted by the community if adequately designed.

In reality, it is much more likely that a more participatory decision-making process will lead to modifications in the practices used. The public's concern with being left out of the process is well-founded: beyond the snub of effective exclusion on a largely public landbase, other values or local considerations are likely to be missed or under-weighted. This underscores the importance of developing the right kind of social process, and particularly a careful, systematic, and even-handed stakeholder analysis (as discussed below).

A final argument for the importance of social processes within SFM is their effectiveness in capacity- and awarenessbuilding. Social learning is a major outcome of participatory 
Table 2. Frequency of different types of social indicators used by the Canadian Model Forests (based on analysis of von Mirbach 2000)

\begin{tabular}{|c|c|c|c|c|c|}
\hline & & & & Model fo & idicators \\
\hline & & & & $\#$ & $\%$ \\
\hline Procedural & $\begin{array}{l}\text { Fair and effective } \\
\text { social processes }\end{array}$ & $\begin{array}{l}\text { Inclusive/equitable } \\
\text { processes }\end{array}$ & $\begin{array}{l}\text { Inclusive of people/institutions } \\
\text { Inclusive of values } \\
\text { Inclusive of ideas/choices/alternatives }\end{array}$ & 49 & \\
\hline & & $\begin{array}{l}\text { Informative process } \\
\text { Effective process }\end{array}$ & $\begin{array}{l}\text { Makes information available/informed decision-making } \\
\text { Efficiently conducted process } \\
\text { Process leads to a conclusive result }\end{array}$ & $\begin{array}{l}9 \\
3\end{array}$ & \\
\hline Outcome-based & $\begin{array}{l}\text { Beneficial or acceptable } \\
\text { social outcomes }\end{array}$ & $\begin{array}{l}\text { Directly measurable } \\
\text { socio-cultural conditions }\end{array}$ & $\begin{array}{l}\text { Recreational opportunities } \\
\text { Visual quality } \\
\text { Quality of water supply } \\
\text { Community stability, etc. }\end{array}$ & 52 & 39 \\
\hline & & Satisfaction/perceptions & $\begin{aligned} \text { Satisfaction with procedures Ecological procedures } \\
\text { Social processes }\end{aligned}$ & ) & \\
\hline & & & $\begin{aligned} \text { Satisfaction with outcomes } & \text { Perceived ecological outcomes } \\
& \text { Perceived economic outcomes } \\
& \text { Perceived social outcomes }\end{aligned}$ & 3 & 2 \\
\hline & & Capacity/understanding & $\begin{array}{l}\text { Level of knowledge and capability in ecological, } \\
\text { economic, and social factors }\end{array}$ & 18 & 13 \\
\hline Total number of & model forest social indicat & rs (criteria 5/6) & & 134 & 100 \\
\hline
\end{tabular}

Source: von Mirbach (2000).

processes (Kruger 2001), and such processes may be more effective than the conventional methods of education and extension activities, due to their hands-on, in-depth nature: learning by doing rather than by being told. Public participation processes may even be the most effective way of getting communities to improve their understanding of SFM issues; this may be a key justification for (and the most beneficial outcome of) the process, even if the planned management activities do not change very much as a result. Equally importantly, an inclusive process also leads to broader learning by the technical "experts" about local conditions and knowledge, such as Traditional Ecological Knowledge (TEK).

\section{The importance of perceptions}

Social C\&Is address human benefits and needs. Is it not reasonable to expect that the humans affected by forest management have some say in the evaluation of SFM performance? Oddly, however, measures of satisfaction with SFM outcomes are still rare in certification and management systems, and largely missing from the basic international agreements. Only three of the 134 social criteria used in the Model Forest System (von Mirbach, 2000) address satisfaction (e.g., "level of satisfaction with how forestry concerns have been addressed"). There are a few other precedents: for example the Forest Stewardship Council's Pacific Coast Regional Guidelines contain a principle on Local Rights that calls, amongst other things, for full and informed consent in relation to activities that affect indigenous peoples and other long-settled forest-dependent communities (Keene 2000). The UK Forestry Standard (Forestry Authority 1998) implies the use of survey techniques in assessing social and aesthetic values (Burley 2001). While it is true that people's perceptions can be used to help gauge achievement of the direct social outcomes (e.g., recreation user surveys can be used to assess the quality of recreation opportu- nities), the greater difficulty of reliably soliciting opinions and feedback from the public naturally shifts the emphasis to quicker and simpler expert-driven methods, unless otherwise required. Is this a problem?

One argument for not using perception information or measures of satisfaction is that they can be biased or sometimes simply wrong - disconnected from the scientific reality of sustainability. However, this argument fails to acknowledge that the science is incomplete. It is itself sometimes proven to be wrong over time, and we have very few of the answers on even the ecological components of sustainability, which have been the most studied. Pragmatically, problems arise when a gulf develops between the prevailing "scientific" wisdom and the more general public perception (Bell 2000). Research has shown that expert judgements of social conditions such as visual quality (Daniel and Vining 1983, Kaplan et al. 1998) can depart markedly from public perceptions. As Tindall (2001a) puts it, "one cannot simply measure things in the woods to understand human and social values associated with forests." While many discrepancies in opinion between experts and lay people can be attributed to lack of knowledge in the general public or affected stakeholders, it would be hard ultimately to claim forestry is socially sustainable if society rejects it as unacceptable over the long term. At some point, the forest manager and the certification auditor alike have to grapple with people-issues head-on.

Public perceptions of forest management outcomes may address not only the social factors (e.g., community stability or recreational access), but also the other types of outcomes, particularly ecological sustainability. Various surveys of public attitudes and opinions (Robson et al. 2000, Tindall, 2001b) have shown the importance to the public of broader ecological or biophysical conditions (e.g., forest health, water quality, forest productivity), even if the short-term direct social effects are not clear and scientists feel that the public perceptions are misin- 
formed. In a recent mail-survey of residents of the Arrow Forest District area in the West Kootenays, we found that the participants consistently weighted water quality and ecological conditions as more important management priorities than direct social factors such as jobs and recreation opportunities (Meitner et al. 2001).

The achievement of public satisfaction with forestry, and therefore of social sustainability, depends in part on society seeing tangible proof that forestry is ecologically sustainable and carefully managed. In short, can you tell that it is good forestry? The following section explores this question and the central importance of the image of forestry relative to the truth, as best we can measure it.

\section{What Does Socially Sustainable Forest Management Look Like? How Can You Tell It Is Sustainable?}

Previous attempts to convey good stewardship have involved a battery of techniques, ranging from the operational to the strategic, and from the subtle to the blunt. They include information signage, public relations (e.g., advertising, marketing, lobbying trips to Europe, and local sponsorship), environmental award schemes, scientific panels, compliance with regulations like the BC Forest Practices Code (FPC), shifts to new management paradigms such as ecosystem management, and certification. These have had at best variable success in shaping public opinion. The FPC, for example, while well intentioned and a major step forward from previous practices in some ways, failed to liberate the $\mathrm{BC}$ forest industry from its environmental detractors. There are many reasons for these social failures, not least the deep pools of distrust that have developed between the traditional timberfocused sector and the ENGOs with their largely urban constituencies. However, I contend that one of the other main reasons for these failures is the lack of correspondence between the stated process, policies, or conditions, and the visible evidence on the ground and in the communities.

The ability of visual evidence to convince large sectors of the public of the sustainability of forestry is undisputed (Kimmins 1999). The Greenpeace Web site from February 2001, for example, used photographs of logging on the coast explicitly as evidence of "unsustainable" forestry (Fig. 2) without providing other supporting scientific evidence: "Any (company) customer who sees these images will know that the company's logging is still threatening the ecosystem of Canada's ancient rainforest" (Greenpeace 2001).

In Special Management Zones (SMZs) designated for special management techniques in light of sensitive resources, people reportedly expect to see special harvesting practices, and are shocked when conventional practices such as clearcutting (which looks like business as usual) are used, even if the rotation length and other parameters are much modified (Larry Pedersen, Chief Forester, BCMOF, personal communication, 2001).

The conclusion that we should draw from this is that for many of the local and global publics, the forest/community setting itself provides the strongest evidence of forestry's performance. To move towards social sustainability, we need to consider the landscape as both a powerful communication device and a potential learning tool.

Kimmins $(1999,2001)$ is right in saying that many indicators of ecological performance are not visible, but while we should not expect all indicators (ecological or indeed, social) to be direct-

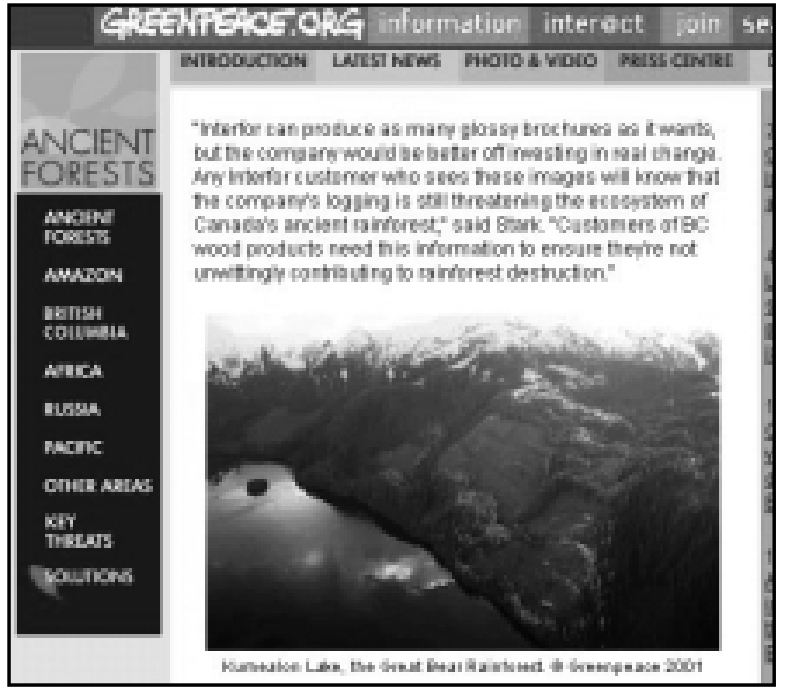

Fig. 2. "One picture is worth a thousand words": photograph from Greenpeace Website, February 2001, used as evidence of unsustainable forestry. [Source: Greenpeace (http://www.greenpeace.org)].

ly visible, we should at least expect some to be visible. Further, I would argue, we should strive to maximize the visibility of key indicators or what symbolizes key non-visible conditions.

The concept of visibly demonstrating sustainable forestry through such methods has been termed "Visible Stewardship" (Sheppard 2001a). This concept is based on the assumption that forest management will not be perceived as good (sustainable) forestry if it fails to demonstrate an obvious and sustained commitment of people to the places and ecosystems under their control. This represents an extension of arguments put forth by Gobster (1995) in favour of an "ecological aesthetic," itself derived from Aldo Leopold (1981). Forest practices that may help to demonstrate sustainable management include information signage, certain forms of partial cutting or variable retention (Fig. 3), which respect social sensitivities, or ecosystem processes, careful landscape design, visible site restoration projects and simply the regular conduct of forest maintenance activities within the community.

Under the concept of visible stewardship, there would appear to be three important tests to determine if satisfactory perceptions of sustainability, based on readily available visible information, are likely to be achieved. These tests can be applied both to procedural C\&Is (forest planning, management, and monitoring processes) and the outcome-based C\&Is (conditions in the forest and community), as suggested in Table 3.

While tests 1 and 2 acknowledge the importance of the perceived image of forestry, test 3 is vital in showing the correspondence (or lack of correspondence) between how things appear and their condition as measured scientifically. Without such tests, we risk the triumph of image over substance-public relations without clear communication of scientific results. It should be recognized that where the forest management achieves test 1 but fails test 2 , forestry is likely to be judged negatively, as occurs with timber harvesting outside the carefully managed visually sensitive areas in B.C. (Picard and Sheppard 2002).

The concept of visible stewardship can be defined narrowly, as a perceptual theory on the messages about forestry that the public reads from the landscape, or more broadly, to 


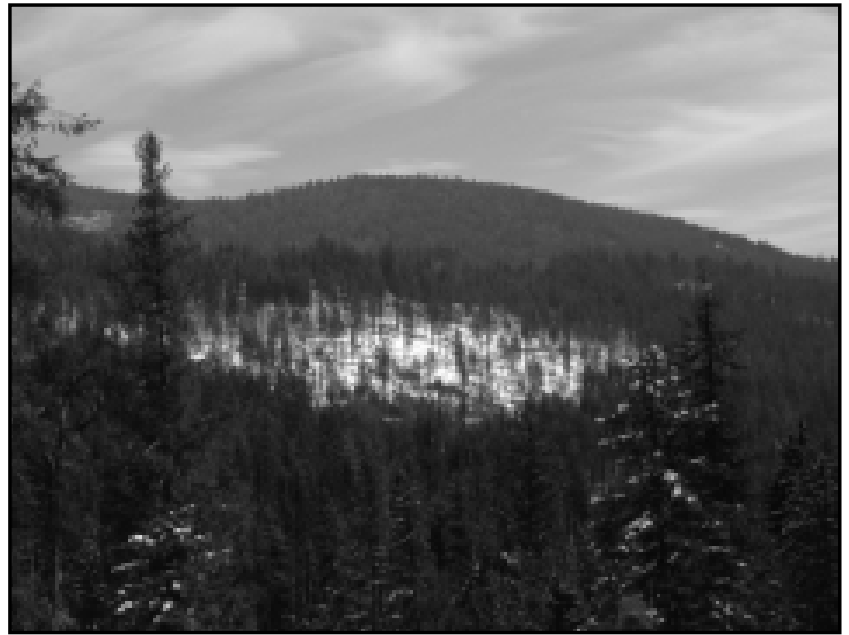

Fig. 3. Partial cutting with dispersed green tree retention remains visible but conveys to the general public a very different message of stewardship than hard-edged clearcuts. Credit: Paul Picard.

include the visibility and transparency of the entire forest planning/management/monitoring process.

\section{Transparent and inclusive processes}

What makes a satisfactory public process in forestry? What might a truly open and accountable planning process look like? The Forest Practices Board (2000) review of the Forest Development Plan (FDP) process in BC provides some pointers in its forthright criticism of current practice and its recommendations for an improved planning process as follows:

- Consideration of the full range of resource values

- Planning at the landscape level

- Earlier public involvement

- More transparency of the process (showing the influence of public input on decision-making)

- More effective public involvement

The review noted that in BC, the FDP public process has not been effective-typically, open houses are not well attended, First Nations consultation is often ineffective to non-existent, the FDP reports are not used by the public, and the FDP maps available for display are not understood by the public. The report cites examples demonstrating that inclusive, respectful public processes are more successful, findings supported by both practitioners (Apostol et al. 2000, Bell 2000) and researchers (Hislop and Twery 2001, Kruger 2001).

Applying the three tests of visible stewardship to the forest planning and management process, we might derive the following description of a good, socially sustainable process:

i) A visible, transparent and open process: activities are well advertised and reported; planning, management, and monitoring activities are visible within the community on a fairly frequent basis; key staff, perhaps even neutral forest stewards, are accessible and prominent in the community; regular public "state of the forest" meetings are held; decisions are clearly documented and rationalized.

ii) A respectful, inclusive process that can be seen to address the range of forest values, integrates local knowledge and expert opinion, involves representative affected stakeholders in activities such as scenario design and monitoring, and reduces conflict (Brown et al. 2001). iii) A defensible, verifiable process: information and decisionsupport tools are validated, expected management outcomes are related to actual experience gained through adaptive management, and the success of the process is clearly demonstrated.

Such processes include a multitude of possible participation techniques. Hislop and Twery (2001) describe over 40 public involvement methods of use to foresters in the UK. A simple way to consider the kinds of techniques needed is to use the following framework based on communication flow:

- One-way communications outward: providing good information to the public, which is pitched at the appropriate (nontechnical) level, with abundant use of good graphics and visualisation (Tufte 1990).

- One-way communications inward: better listening to the publics, including the "silent majority" that often does not get heard amidst the arguments; this can be achieved through social science tools such as mail surveys and websurveys (Meitner et al., 2001 Tindall 2001b).

- Two-way communications: better dialogue with the public(s) through collaborative planning and design processes, and other methods of moving towards agreement or acceptance of a desired forest future.

An example of a comprehensive approach testing some of these improved methods of participatory decision support (see Fig. 4) has been conducted under the Arrow Forest District Innovative Forest Practices Agreement (IFPA) studies in the West Kootenays (CALP 2001, Sheppard et al. 2002). A District-wide mail survey has been conducted (Meitner et al. 2001) to gauge public attitudes towards multiple resource values and forest practices. A comprehensive stakeholder analysis was undertaken to identify and classify the various interest groups in terms of their influence on the decision-making process and the degree to which they are affected by forest management decisions. A pilot decision support process has been tested at the landscape level in the Lemon Landscape Unit of the Slocan Valley area. A balanced sample of interest groups was invited to comment upon and prioritize a range of C\&Is in the analysis of alternative forest management scenarios. A form of Multi-Criteria Analysis (MCA) is being used to evaluate trade-offs between differing resource priorities (C\&Is) and alternatives (Mendoza et al. 1999, Brown et al. 2001, Sheppard 2001b). Based on initial findings and international experience in other settings (Brown et al. 2000, De Marchi et al. 2000), this approach promises to provide a comprehensive, systematic, and transparent record of how different interest groups evaluate scenarios and where areas of commonality lie, for use by the decision-makers in rationalising their resource management decisions. Further work on making stakeholders' trade-offs between SFM criteria more transparent is continuing.

One of the innovations being tested in this pilot process is the use of advanced landscape visualisations to convey and compare forest management scenarios over time. Members of the Collaborative for Advanced Landscape Planning (CALP) at UBC have developed new methods of generating realistic datadriven 3D visualisations for landscape level databases (Fig. 5), integrating terrain data, harvesting plans, vegetation growth modeling, and photographic image databases (CALP 2001, Meitner 2001). The potential of such techniques to illustrate forest plans, explain complex spatial and temporal relationships, and support decision-making, has been well documented 
i) Is there visible evidence of the planning/ management process undertaken or sustainability outcomes?

ii) If so, does the visible evidence look good, (suggesting that there is good forestry going on)?

iii) Can you verify whether the visible evidence reflects the truth, i.e., that what looks good is good, or that what looks bad may actually be good?

\section{Examples}

Can you see that forest management activities are taking place? Is there any way to tell whether fish populations in nearby streams are healthy?

Do the forest management activities look appropriate? Do the fish populations seem healthy and stable?

Is there any other corroborating information (e.g., community discourse, signs, monitoring information, etc.) readily available on the appropriateness of or rationale for the management activities? Is there any evidence that the dead fish visible in the creek are a natural phenomenon and not caused by bad logging practices?

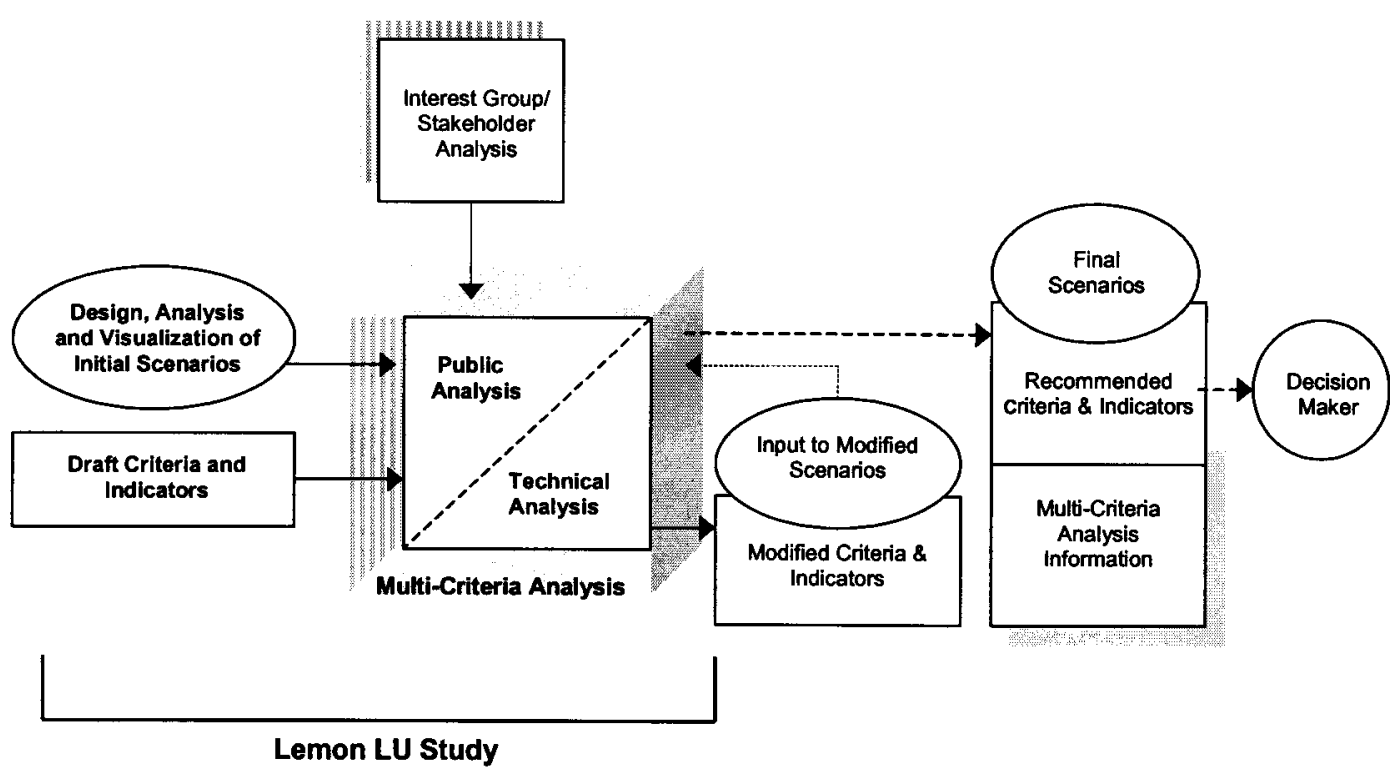

Fig. 4. Flowchart of the Pilot Decision-support Approach for the Arrow IFPA.

(Orland 1997, Sheppard 2000, McGaughey 2001). However, there is inadequate scientific evidence of the utility and validity of these techniques. This is one of the contributions we hope to make through the pilot landscape planning process. In early work using photo-realistic imagery to convey ecological and cultural alternatives to watershed restoration and forest management plans with First Nation groups, we have demonstrated the considerably improved utility of visualisations over conventional maps (Lewis 2000). Clearly, the ability of visualisation to make the planning process more visible and to provide at least a forecast of sustainability to non-technical viewers represents a powerful tool in the toolbox for expressing visible stewardship and promoting inclusive techniques, although there is some concern over the dangers of misleading the public with such techniques inappropriately applied (Luymes 2001, Sheppard 2001c).

\section{Some Implications and Some Questions Results-based approaches and policies}

What are the implications of these assertions about the importance of the public process and the need for Visible Stewardship, for a results-based system as in certification or the Forestry Code in $\mathrm{BC}$ ?
An inclusive and transparent public planning process may be vital to building or rebuilding trust in forestry. A results-based approach that asks the public to trust the forestry professionals and wait five or more years before seeing any evidence of sustainability is unlikely to succeed in the present climate of opinion. The end may not justify the means. Ignoring process and relying solely on performance is inadequate in ensuring social sustainability, unless we include public satisfaction with both outcomes and process as a key indicator. Selecting or developing the right kind of process, fitted to the social setting(s) involved, is important. How, for example, will the emerging social groups of risk-recreation users (e.g., climbers, mountain bikers) be handled equitably in the forest management process, alongside more conventional recreation users such as trappers and hunters?

$\mathrm{BC}$ has experimented with several public planning processes, such as the CORE process and Land and Resource Management Plans (LRMPs). These consensus-based processes have sometimes been successful in developing legitimate accepted land use plans, while narrowing differences between interest groups (CORE 1995). However, they can drag out for many years and have attracted criticism as a forum for entrenched bargaining rather than broader collaboration. In some quarters, there is a reluctance to experiment further with public involvement, since 

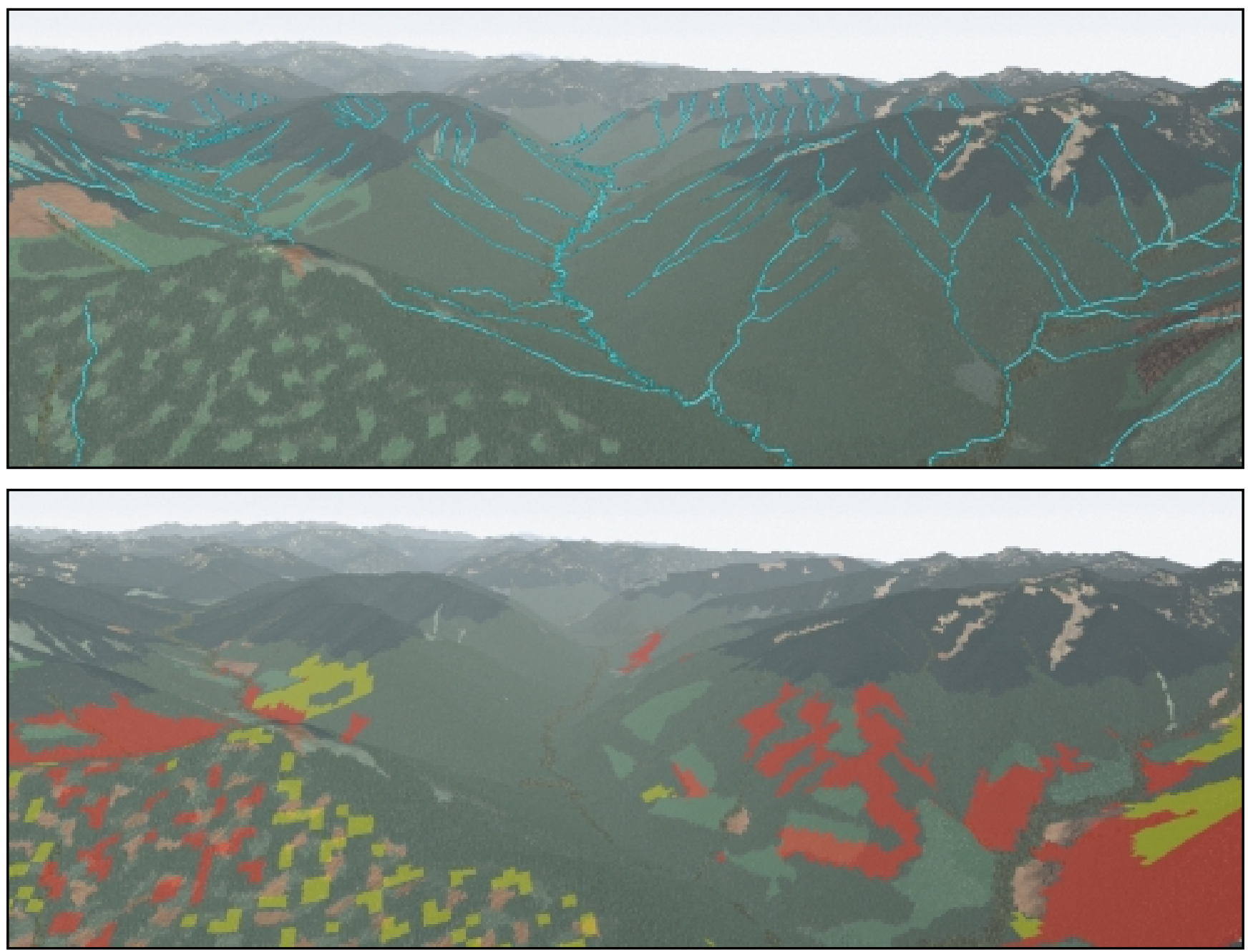

Fig. 5. Experimental landscape visualisations of the Lemon Creek valley in BC, showing a future harvesting scenario overlaid with mapped streams (top) and habitat quality modelling (good \& moderate) for Swainson's thrush (bottom). Credit: Jon Salter/Duncan Cavens (CALP) \& Ralph Wells/Stephanie Melles (UBC).

the past experiences have been so negative. Other jurisdictions in $\mathrm{BC}$ and around the world have progressed to more advanced models and procedures for participatory decision-making, for example, some of the regional districts in BC, the US Forest Service, and the UK Forestry Commission. We can learn from them and at the same time develop our own models at the appropriate planning scales, through projects like the Arrow Innovative Forest Practices Agreement (IFPA), Enhanced Forest Management Pilot Projects, and the Model Forest Program.

We also need to be sure that the results of sustainable forest management that people see reflect the results we are claiming scientifically. Continuing mismatches between what people perceive and what the foresters say will risk discrediting any new system. The gap needs to be closed as far as possible, both through design/practice, and through education and capacity-building. A new Visual Resource Management system that incorporates the concept of Visible Stewardship could be introduced, promoting acceptable forestry that does not have to be hidden from the public view (Hull et al. 2000) or disguised as "natural." Collaborative planning processes can play a key role in advancing community understanding of forestry issues and securing "buy-in" to the process.
Lastly, considerable effort should be put into developing best practices for public involvement and planning with a suite of participatory decision-support tools for practitioners, along the lines of the UK Forestry Commission guides (Hislop and Twery 2001).

\section{Streamlining approvals}

Hand in hand with the desire for results-based forest management goes the desire to streamline processes and cut unnecessary red tape. The ideas explored above offer some advantages in this area. While the public processes described above may seem to increase the workload, in terms of a more thorough stakeholder analysis at the outset and more intensive consultation and collaboration throughout, we can see this as streamlining via inclusion versus exclusion. Any process that avoids or reduces the substantial delays, costs, and uncertainties inherent in the often adversarial and special-interest-oriented system that exists today should be welcomed. Interest groups excluded from the process often find a way to block it ultimately, because they feel their voices are not being heard or given due importance. By including the weight of moderate opinions through survey techniques to reach the "silent majority" or a wider range of opin- 
ion, the potential for closing down processes by those with extremist viewpoints may be reduced.

Techniques such as visualisation offer significant advantages in speeding and improving people's understanding of the issues. Other technological advances may contribute also. GIS on every forester's desk, as is being implemented for the staff of the UK Forest Enterprise, can yield considerable savings in time and money. Better mapping of socio-cultural factors, such as history, special places, landscape meanings, and traditional uses (inside and outside First Nation communities) would speed up data gathering and analysis.

\section{Education and research}

Given the current gap between the need for better social processes and the training of the typical Registered Professional Forester (RPF), there is a need for substantial retraining, as well as new curriculum developments for up-and-coming foresters. Nothing less than resocializing the forester is needed. We need to give practitioners the tools and training to deliver the social performance required and regain the trust of the public.

Clearly, foresters are asking for this knowledge. In both Tindall's survey of Forestry students (Tindall 2001c), and the recent Forest Management Institute of British Columbia survey of RPFs (FMIBC 2001), many of those surveyed placed a high priority on addressing "people issues" in forest management. We may soon be seeing the day when foresters become more generalist integrators of knowledge, running interdisciplinary teams and deploying a range of analytical, design, and communications skills to solve today's more complex forestry problems.

At UBC, we are responding with substantial shifts in the BSF curriculum, and the development of a proposed new Master's degree in Forests and Society. There is much time to make up for skills not taught until recently to the budding forester, especially to graduates who should lead the charge in retraining current practitioners. Forestry faculties need to reflect a wide range of disciplines, including sociology, political science, economics, environmental psychology and landscape architecture.

In research, we need to continue the experiments on large-scale forest planning with inter-disciplinary collaborative teams, integrating academic, practitioner, First Nations, and local knowledge. At CALP we plan further development and testing of visual information systems, using visualisation as the medium for design and communications, not just maps. More work needs to be done to develop interactive interfaces to visualisations and supporting models, allowing users easily to see and understand non-visible information on habitat, operations, productivity, etc. We also need to understand better the effects of visualisation on decisionmaking - are they valid tools, and can they unfairly bias the process? What ethical guidelines (Sheppard 2000) should be followed in applying such powerful tools?

\section{Conclusions}

The main conclusions of this review are that:

- Process is important in forest planning, not just the results. Also the type and quality of the process is key: collaborative planning methods should be developed to ensure more streamlined, transparent, and inclusive processes.

- The satisfaction of the public with SFM and people's perceptions of forestry are important components of social sustainability; therefore, the image of forestry and its links to scientific reality are crucial.
- The concept of visible stewardship needs to be tested in practice; paying attention to the appearance and information content of the landscape, and visibly demonstrating good planning, management and monitoring over the long term.

- Training and retraining foresters to build their skills and confidence in these social sustainability aspects is an urgent priority if forestry's performance is to be judged as satisfactory by society.

Taking on these challenges may prove vital if the public is to trust the forestry profession and if we are to see socially sustainable forests in Canada.

\section{References}

Achiam, C. and S.R.J. Sheppard. 2001. Socio-cultural Criteria and Indicators for the Arrow IFPA Sustainability Project. Draft report. Collaborative for Advanced Landscape Planning, UBC, Vancouver, BC. Allen, K. and D. Frank. 1994. Community forests in British Columbia: Models that work. For. Chron. 70(6): 721-724.

Anon. 1995. Criteria and indicators for the conservation and sustainable management of boreal and temperate forests: the Montreal Process. Canadian Forest Service, Hull, Quebec.

Apostol, D., M. Sinclair and B. Johnson. 2000. Design your own watershed: Top-down meets bottom-up in the Applegate Valley. In R.G. D'Eon, J.F. Johnson and E.A. Ferguson (eds.). Ecosystem Management of Forested Landscapes: Directions and Implementation. Proceedings of Conference on Ecosystem Management of Forested Landscapes, 26-28 October 1998, Nelson, BC. pp. 45-50. UBC Press, Vancouver, BC.

BC Ministry of Forests (BCMOF). 1998. Recreation Opportunity Spectrum Inventory Procedures and Standards Manual Version 3.0. Resources Inventory Committee, BCMOF Forest Practices Branch, Victoria, BC. 41 p.

BC Ministry of Forests (BCMOF). 2001. Visual Impact Assessment Guidebook. $2^{\text {nd }}$ edition. BCMOF Forest Practices Branch, Victoria, BC. $64 \mathrm{p}$.

Bell, S. 2000. Ensuring the social acceptability of ecosystem management. In R.G. D'Eon, J.F. Johnson and E.A. Ferguson (eds.). Ecosystem Management of Forested Landscapes: Directions and Implementation. Proceedings of Conference on Ecosystem Management of Forested Landscapes, 26-28 October 1998, Nelson, BC. pp. 69-84. UBC Press, Vancouver, BC.

Brand, D.G. 1997. Criteria and indicators for the conservation and sustainable management of forests: progress to date and future directions. Biomass and Bioenergy 13 (4/5): 247-253.

Brown, K., E. Tompkins and W.N. Adger. 2001. Trade-off analysis for participatory coastal zone decision-making. University of East Anglia, Overseas Development Group, Norwich, UK. 109 p.

Brown, K., W.N. Adger, E. Tompkins, P. Bacon, D. Shim and K. Young. 2000. Trade-off analysis for marine protected area management. CSERGE Working Paper GRC 2000-02. University of East Anglia, Norwich, UK. 32 p.

Burley, J. 2001. International initiatives for the sustainable management of forests. Chapter 7: In S.R.J. Sheppard and H.W. Harshaw (eds.). Forests and Landscapes Linking Ecology, Sustainability and Aesthetics. pp. 95-102 IUFRO Research Series, No. 6. CABI Publishing, Wallingford, UK. Collaborative for Advanced Landscape Planning (CALP). 2001. Arrow Forest District Innovative Forest Practices Agreement: Socioeconomic Technical Report. UBC, Vancouver, BC. 23 p.

Canadian Council of Forest Ministers (CCFM). 1995. The Canadian approach: Criteria and indicators of sustainable forest management. Hull, Quebec.

Commission on Resources and Environment (CORE). 1995. The Provincial land use strategy. Vol. 3: Public Participation. Victoria, B.C. 153 p. Daniel, T.C. and J. Vining. 1983. Methodological issues in the assessment of landscape quality. In I. Altman and J.F. Wohlwill (eds.). Behaviour and the Natural Environment. pp. 39-84. Plenum, New York. NY. 
De Marchi, B., S.O. Funtowicz, S. Lo Cascio and G. Munda. 2000. Combining participative and institutional approaches with multicriteria evaluation: an empirical study for water issues in Troina, Sicily. Ecological Economics 34 (special issue on social processes of environmental evaluation): 267-282.

Forestry Authority. 1998. The UK Forestry Standard - the Government's Approach to Sustainable Forestry. Prepared by the Forestry Commission and Department of Agriculture for Northern Ireland. The Forestry Commission, Edinburgh, UK.

Forest Management Institute of BC (FMIBC). 2001. Toward a Forest Management Diploma Program: Report on a survey of interest, topics, and delivery. Vancouver, BC. 23 p.

Forest Practices Board. 2000. A review of the Forest Development Planning process in BC. FPB/SR/04. 75 p. http://www.fpb.gov.bc.ca/ reports/special/fdp/index.htm.

Gobster, P.H. 1995. Aldo Leopold's ecological aesthetic: Integrating esthetic and biodiversity values. J. For. 93(2): 6-10.

Greenpeace. 2001. Retrieved February 28, 2001 from http://www.greenpeace.org

Hislop, M. and M. Twery. 2001. A decision-framework for public involvement in forest design planning. Final Report for Policy and Practice Division of the Forestry Commission on a joint project between Forest Research and the USDA Forest Service Northeastern Research Station. Forest Research, UK Forestry Commission, Roslin, Scotland. Hull, R.B., D. Robertson, G. Buyhyoff and A. Kendra. 2000. What are we hiding behind the visual buffer strips? Forest Aesthetics reconsidered. J. For. 98(7): 32-36.

Kaplan, R., S. Kaplan and R.L. Ryan. 1998. With People in Mind. Island Press, Washington, DC. 225 p.

Keene, R. 2000. Excerpts from a critique of Forestry Stewardship Council's Pacific Coast Regional Guidelines for Third Party Forest Product Certification. http://www.publicforestry.org/WritingsArchive/Reports/ FSCCritique.html.

Kimmins, J.P. 1999. Biodiversity, beauty and the Beast - are beautiful forests sustainable, are sustainable forests beautiful, and is "small" always ecologically desirable? For. Chron. 75: 955-960.

Kimmins, J.P. 2001. Visible and non-visible indicators of forest sustainability: Beauty, beholders, and belief systems. Chapter 4. In S.R.J. Sheppard and H.W. Harshaw (eds.). Forests and Landscapes: Linking Ecology, Sustainability, and Aesthetics. pp. 43-56. IUFRO Research Series, No. 6. CABI Publishing, Wallingford, UK.

Kruger, L.E. 2001. What is essential is invisible to the eye. Chapter 12. In S.R.J. Sheppard and H.W. Harshaw (eds.). Forests and Landscapes: Linking Ecology, Sustainability, and Aesthetics. pp. 173-187. IUFRO Research Series, No. 6. CABI Publishing, Wallingford, UK Leopold, A. 1981 (originally published 1949). A sand county almanac and sketches from here and there. Oxford University Press, NY.

Lewis, J.L. 2000. Ancient values, new technology: Emerging methods for integrating cultural values in forest management. Unpublished MSc. Thesis, Faculty of Forestry, UBC, Vancouver, BC.

Luymes, D. 2001. The rhetoric of visual simulation in forest design: some research directions. Chapter 13. In S.R.J. Sheppard and H.W. Harshaw (eds.). Forests and Landscapes: Linking Ecology, Sustainability, and Aesthetics. pp. 191-204. IUFRO Research Series, No. 6. CABI Publishing, Wallingford, UK.

McGaughey, R.J. 2001. Data-driven visualization of forest management alternatives using EnVision. In Compendium of the Visual Resource Management Conference, Seeing Beyond the Trees: Visual Stewardship of the Working Forest, April 17-19, 2001, Kamloops, BC. pp. 41-49. Meitner, M. 2001. Visualization as a decision support tool. In Compendium of the Visual Resource Management Conference, Seeing Beyond the Trees: Visual Stewardship of the Working Forest, April 17-19, 2001, Kamloops, BC. pp. 191-192.

Meitner, M.J., S.R.J. Sheppard and H.W. Harshaw. 2001. Arrow Forest District Social Values Survey Final Report. Arrow IFPA Technical Report. Dept. of Forest Resources Management, UBC, Vancouver, BC.
Meitner, M.J., H.W. Harshaw, S.R.J. Sheppard and P. Picard. 2002. Criterion 9: Quality of life benefits. Arrow IFPA Sustainability project extension note series, No. 9 Draft. Dept. of Forest Resources Management, UBC, Vancouver, BC. 5 p.

Mendoza, G.A. and P. Macoun with R. Prabhu, D. Sukadri, H. Purnomo and H. Hartanto. 1999. Guidelines for applying Multi-Criteria Analysis to the assessment of criteria and indicators. C\&I Tool No. 9 in The Criteria and Indicators Toolbox Series. Center for International Forestry Research, Jakarta, Indonesia.

Orland, B. 1997. Forest virtual modelling for planners and managers. In Procs. American Society for Photogrammetry and Remote Sensing (ASPRS) Annual Convention/RT'97, April 7-10, 1997. Seattle, Washington.

Picard, P. and S.R.J. Sheppard. 2002. Visual resource management in British Columbia-Part I: The effects of visual resource management on timber availability: A review of case studies and policy. BC Journal of Ecosystems and Management 1(2): 85-102.

Robson, M., A. Hawley and D. Robinson. 2000. Comparing the social values of forest-dependent, provincial and national publics for socially sustainable forest management. For. Chron. 76(4): 615-622.

Sheppard, S.R.J. 2000. Visualization as a decision-support tool for managing forest ecosystems. The Compiler 16(1): 25-40.

Sheppard, S.R.J. 2001a. Beyond visual resource management: emerging theories of an ecological aesthetic and visible stewardship. Chapter 11. In S.R.J. Sheppard and H.W. Harshaw (eds.). Forests and Landscapes: Linking Ecology, Sustainability, and Aesthetics. IUFRO Research Series, No. 6. CABI Publishing, Wallingford, UK.

Sheppard, S.R.J. 2001b. Multi-criteria accounting and trade-off analysis. Paper presented at Symposium on Sustainable and Performance-based Resource Management: Lessons and Predictions from the Working Forest, October 24-25, 2001, Richmond, BC.

Sheppard, S.R.J. 2001c. Guidance for crystal ball gazers: developing a code of ethics for landscape visualization. Landscape and Urban Planning 54:183-199. Elsevier Science B.V.

Sheppard, S.R.J., M.J. Meitner, N.Wilson, H. Harshaw and C. Pearce. 2002. Public procession in sustainable forest management. Arrow IFPA Sustainability Project Extension Note Series, No. 3 Draft. Dept. of Forest Resources Management, UBC, Vancouver, BC. 5 p.

Sheppard, S.R.J. and C. Achiam. 2001. Forest certification and aesthetics: proposed criteria and indicators for visible stewardship. In Compendium of the Visual Resource Management Conference, Seeing Beyond the Trees: Visual Stewardship of the Working Forest, April 17-19, 2001, Kamloops, BC. pp. 107-118.

Shindler, B. and L.A. Cramer. 1999. Shifting public values for forest management: Making sense of wicked problems. Western Journal of Forestry 14(1): 1-7.

Stankey, G.H. 1996. Defining the social acceptability of forest management practices and conditions; Integrating science and social choice. In M.W. Brunson, L.E. Kruger, C.B Tyler and S.A. Schroeder (eds.). Defining Social Acceptability in Ecosystem Management: A Workshop Proceedings; June 23-25, 1992, Kelso, WA. pp. 99-111. Gen. Tech. Rep. PNW-GTR-369. USDA Forest Service, Pacific Northwest Research Station, Portland, OR.

Sustainable Forest Management Network. 2001. Research Program, 2001/2001. SFM Network, University of Alberta, Edmonton, Alberta. $97 \mathrm{p}$.

Tindall, D.B. 2001a. Why do you think that hillside is ugly? A sociological perspective on aesthetic values and public attitudes on forests. Chapter 5. In S.R.J. Sheppard and H.W. Harshaw (eds.). Forests and Landscapes: Linking Ecology, Sustainability, and Aesthetics. pp. 57-70. IUFRO Research Series, No. 6. CABI Publishing, Wallingford, UK.

Tindall, D.B. 2001b. Variation in public values and visual quality preferences. In Compendium of the Visual Resource Management Conference, Seeing Beyond the Trees: Visual Stewardship of the Working Forest, April 17-19, 2001, Kamloops, BC. pp. 215-234. 
Tindall, D.B. 2001c. Social science and forestry curricula: Some survey results. For. Chron. 77(1): 121-126.

Tufte, E.R. 1990. Envisioning Information. Graphics Press. Cheshire, Conn. $126 \mathrm{p}$.

von Mirbach, M. 2000. A User's Guide to Local Level Indicators of Sustainable Forest Management: Experiences from the Canadian Model Forest Network. Natural Resources Canada, Canadian Forest Service, Ottawa, ON. 265 p.
Webb, J. 2001. Building capacity through leading edge research. Tomorrow's Forests. The Sustainable Forest Management Network Newsletter, Summer 2001. p 1, 19.

White, W. 2001. Social and economic aspects of community sustainability: results from the Robson Valley Enhanced Forest Management Pilot Program (EFMPP). Paper presented at Symposium on Sustainable and Performance-based Resource Management: Lessons and Predictions from the Working Forest, October 24-25, 2001, Richmond, BC. 